\title{
Article
}

\section{WNK1 is required for proliferation induced by hypotonic challenge in rat vascular smooth muscle cells}

\author{
Ya-juan ZHANG", Hua-qing ZHENG\#, Bao-yi CHEN, Lu SUN, Ming-ming MA, Guan-lei WANG, Yong-yuan GUAN* \\ Department of Pharmacology, Cardiac and Cerebral Vascular Research Center, Zhongshan School of Medicine, Sun Yat-Sen University, \\ Guangzhou 510080, China
}

\begin{abstract}
Hypotonic challenge evoked vascular cell proliferation through activation of volume-regulated $\mathrm{Cl}^{-}$channel (VRCC), leading to a decrease in the intracellular $\mathrm{Cl}^{-}$concentration $\left(\left[\mathrm{Cl}^{-}\right]_{i}\right)$. We hypothesize that the decrease in $\left[\mathrm{Cl}^{-}\right]_{\mathrm{i}}$ may activate one or several $\mathrm{Cl}^{-}$-sensitive $\mathrm{kinases}$, resulting in a subsequent signaling cascade. In this study we demonstrated that WNK1, a $\mathrm{Cl}^{-}$-sensitive kinase, was involved in VRCCinduced proliferative signaling pathway in A10 vascular smooth muscle cells in vitro. A10 cells were exposed to a hypotonic challenge (225 mosmol $\left.\cdot \mathrm{kg}^{-1} \cdot \mathrm{H}_{2} \mathrm{O}\right)$, which caused significantly increase in WNK1 phosphorylation without altering WNK1 protein expression. WNK1 overexpression significantly increased hypotonic-induced A10 cell proliferation, whereas silencing of WNK1 caused an opposite action. WNK1 mutation did not affect hypotonic-induced WNK1 phosphorylation and cell proliferation. Silencing of WNK1 caused cell cycle arrest at $G_{0} / G_{1}$ phase and prevented transition from $G_{1}$ to $S$ phase, whereas the WNK1 overexpression accelerated cell cycle transition from $\mathrm{G}_{1}$ to $S$ phase. Silencing of WNK1 significantly inhibited cyclin D1/cyclin E1 expression and increased p27KIP/p21CIP expression. WNK1 overexpression significantly increased cyclin D1/cyclin E1 expression and reduced p27 $7^{\mathrm{KIP}} / \mathrm{p} 21^{\mathrm{CIP}}$ expression. In addition, WNK1 knockdown or overexpression significantly attenuated or increased the hypotonic-induced phosphorylation of Akt and PI3K respectively. In conclusion, the reduction in $\left[\mathrm{Cl}^{-}\right]_{i}$ caused by hypotonic challenge-induced VRCC opening evokes WNK1 phosphorylation in A10 VSMCs, which mediates cell cycle transition from $\mathrm{G}_{0} / \mathrm{G}_{1}$ to $\mathrm{S}$ phase and proliferation through the PI3K-Akt signaling pathway.
\end{abstract}

Keywords: vascular smooth muscle cells; A10 cells; cell proliferation; hypotonic solution; WNK1; cell cycle regulators; PI3K-Akt signaling

Acta Pharmacologica Sinica (2018) 39: 35-47; doi: 10.1038/aps.2017.56; published online 3 Aug 2017

\section{Introduction}

In the healthy cell, the cell volume remains stable. However, alterations in cell volume occur in many physiological and pathophysiological processes, such as cell differentiation, proliferation, migration, and apoptosis ${ }^{[1,2]}$. A swollen cell can return to normal size via regulatory volume decrease (RVD). $\mathrm{K}^{+}$and $\mathrm{Cl}^{-}$flow out through channels or transporters, resulting in the passive transport of water out of cells ${ }^{[3,4]}$. As an anion channel, the volume-regulated $\mathrm{Cl}^{-}$channel (VRCC) is involved in volume-activated $\mathrm{Cl}^{-}$transport from inside the cell to outside the cell. During the return of the cell to a normal volume, $\mathrm{Cl}^{-}$ efflux is regulated by VRCC ${ }^{[1,3-5]}$. As is generally understood, VRCC mediates cell swelling-dependent physiological and pathophysiological processes. Our previous study revealed

\footnotetext{
\# These authors contributed equally to this work.

*To whom correspondence should be addressed.

E-mail guanyy@mail.sysu.edu.cn

Received 2017-01-04 Accepted 2017-04-07
}

that hypotonic challenge evoked vascular smooth muscle cell (VSMC) proliferation, macrophage-derived foam cell formation and inflammation through the activation of VRCC. These hypotonic challenge effects were associated with a decrease of the intracellular $\mathrm{Cl}^{-}$concentration $\left(\left[\mathrm{Cl}^{-}\right]_{\mathrm{i}}\right)^{[5-9]}$. The mechanisms of the response to alterations in $\left[\mathrm{Cl}^{-}\right]_{\mathrm{i}}$ induced by VRCC are unknown. We propose that the decrease in $\left[\mathrm{Cl}^{-}\right]_{\mathrm{i}}$ may activate one or more $\mathrm{Cl}^{-}$sensitive kinases, resulting in a subsequent signaling cascade. It has been shown that some kinases and proteins are sensitive to $\mathrm{Cl}^{-[10]}$. Some studies have shown that WNK1 [with-no-lysine (K)-1], which belongs to the WNK serine/threonine kinase family, is sensitive to $\mathrm{Cl}^{-}$. WNK1 exists in the cardiovascular system, including the heart, vessels and endothelium, and mediates hypertension-hyperkalemia syndrome, cardiac growth, control of blood pressure and postnatal angiogenesis $^{[11-16]}$. We have demonstrated that exposure to a hypotonic solution evoked VRCC activity and $\mathrm{Cl}^{-}$efflux in A10 vascular smooth muscle cells (A10 VSMCs; rat aortic smooth muscle cell line). Therefore, in this study, we investigated 
whether WNK1, a chloride sensor, is involved in the VRCCinduced proliferative signaling pathway in A10 VSMCs. Our results strongly suggest that VRCC reduces $\left[\mathrm{Cl}^{-}\right]_{\mathrm{i}}$, leading to the activation of WNK1 through phosphorylation. Activated WNK1 further evokes a downstream signaling cascade, resulting in cell proliferation.

\section{Materials and methods Solution preparation}

A hypotonic solution was made by adding $75 \mathrm{~mL}$ of $\mathrm{H}_{2} \mathrm{O}$ to $225 \mathrm{~mL}$ of DMEM/F12 medium. The solution osmolarity, as measured with a freezing point depression osmometer (OSMOMAT030, Gonotec, GmbH, Berlin, Germany), was 225 mosmol $\cdot \mathrm{kg}^{-1} \cdot \mathrm{H}_{2} \mathrm{O}$. The control isotonic medium contained 225 $\mathrm{mL}$ of DMEM/F12 medium plus $75 \mathrm{~mL}$ of a mannitol solution (which contained, in mmol/L: $\mathrm{NaCl} 110.8, \mathrm{KCl} 2.5, \mathrm{MgCl}_{2} 0.5$, $\mathrm{CaCl}_{2}$, HEPES 10, glucose, mannitol 75, $\mathrm{pH}$ 7.4), and the final osmotic pressure was $300 \mathrm{mosmol} \cdot \mathrm{kg}^{-1} \cdot \mathrm{H}_{2} \mathrm{O}$.

\section{Cell culture}

The culture of A10 VSMCs from American Type Culture Collection (Rockville, MD, USA) was carried out as previously described ${ }^{[5]}$. Briefly, A10 cells were grown in Dulbecco's modified Eagle's medium/F12 medium with 10\% new-born calf serum (NCS), $100 \mathrm{\mu g} / \mathrm{mL}$ streptomycin, and $100 \mathrm{U} / \mathrm{mL}$ penicillin. Cultures were maintained at $37^{\circ} \mathrm{C}$ in a humidified incubator in a $95 \% \mathrm{O}_{2}$ plus $5 \% \mathrm{CO}_{2}$ atmosphere.

\section{The construction and transfection of plasmids and site-directed mutants}

Cells were plated in 35-mm tissue culture plates. After $24 \mathrm{~h}$, cells were transfected with $1 \mu \mathrm{g} / \mathrm{mL}$ of the Prk5-h WNK1 cDNA plasmid (the prk5-hWNK1 cDNA plasmid was kindly provided by Dr SHIBUYA, Medical Research Institute Tokyo Medical and Dental University), which contains a full-length hWNK1 cDNA and a prk5 vector. The vector contains an ampicillin-resistant marker.

The mutation of tyrosine 60 in hWNK1 (T60A) was generated by site-directed mutagenesis. The primers for the site-directed mutagenesis of hWNK1 were: T60A: forward, 5'-CCGCCGCCACGCTATGGACAAGGAC-3', reverse, 5'-GTCCTTGTCCATAGCGTGGCGGCGG-3' ${ }^{[17]}$ Transfection was performed with Lipofectamine 2000 reagent according to the manufacturer's instructions (Life Technologies, Inc, Invitrogen, CA, USA). Expression of the hWNK1 protein was detected by Western blot analysis. cDNA and Lipofectamine were diluted in Opti-MEMI and mixed 5 min later. After 5 $\mathrm{min}$, they were allowed to combine for $25 \mathrm{~min}$ at room temperature to allow the formation of transfection complexes . The complexes were then added to the cells. After incubation for $5-7 \mathrm{~h}$ at $37^{\circ} \mathrm{C}$, the transfection mixture was removed and the cells were further incubated under normal growth conditions before being used for experiments.

\section{siRNA transfection}

Anti-WNK1 siRNA and negative siRNA were transfected into A10 cells by using hiperfect transfection reagent according to the protocol previously described ${ }^{[7]}$. Antisense and sense oligonucleotides corresponding to the initiation codon region of rat WNK1 mRNA were synthesized (Invitrogen Life Technologies, Inc., Carlsbad, CA, USA). The sequence of the stealth siRNA duplex oligoribonucleotides against the WNK1 gene (GenBank Accession No. NM_116477) is 5'-GGUGUCGGCAAAUCCUUAATT-3'. The corresponding complementary strand is $5^{\prime}$-UUAAGGAUUUGCCGACACCTT-3'. A total of $20 \mathrm{nmol} / \mathrm{L}$ WNK1 siRNA was transiently transfected with hiperfect according to the manufacturer's instructions. The negative stealth siRNA sequence was used as a control. Briefly, siRNA and hiperfect were diluted in Opti-MEMI (Invitrogen Life Technologies, Inc) and then combined for $20 \mathrm{~min}$ at room temperature to allow for the formation of transfection complexes. Complexes were added to the cells while they were in the quiescent state; they were then swirled gently to ensure uniform distribution. After incubation for $6-8 \mathrm{~h}$ at $37^{\circ} \mathrm{C}$, the transfection mixture was removed and the cells were further incubated under normal growth conditions before being used for experiments.

\section{Western blot analysis}

To examine related protein expression, A10 VSMCs were rinsed with ice cold phosphate-buffered saline $(\mathrm{mmol} / \mathrm{L}$ : $\mathrm{NaCl} 140, \mathrm{KCl}$ 2.6, $\mathrm{KH}_{2} \mathrm{PO}_{4}, \mathrm{Na}_{2} \mathrm{HPO}_{4}, \mathrm{pH}$ 7.2). The lysis buffer consisted of (mmol/L): Tris- $\mathrm{HCl} 50, \mathrm{NaCl} 150, \mathrm{NaN}_{3}$ $0.02 \%$, Nonidet P-40 1\%, SDS $0.1 \%$, sodium deoxycholate $0.5 \%$, and $1 \%$ protease inhibitor cocktail (Sigma Chemical, St Louis, MO, USA). The protein content of cell lysates was quantified with a BCA Protein Assay Kit (Thermo Scientific), separated by SDS-PAGE, and transferred to polyvinylidene fluoride (PVDF) membranes (Millipore Corp., Bedford, MA, USA). The membranes were blocked at room temperature for $1 \mathrm{~h}$ in $5 \%$ skim milk diluted in TBST $(140 \mathrm{mmol} / \mathrm{L} \mathrm{NaCl}, 49.6$ $\mathrm{mmol} / \mathrm{L}$ Tris, $0.1 \%$ Tween, $\mathrm{pH} 7.5$ ), incubated for $1 \mathrm{~h}$ at room temperature with primary antibodies, and then incubated with the appropriate secondary peroxidase-conjugated antibodies (HRP-linked anti-rabbit or anti-mouse secondary antibody and HRP-linked anti-biotin antibody, $1 \mathrm{~h}$ at room temperature). Final blots were examined with a BIO-RED Molecular Imager, ChemiDoc XRS+. The density of the bands was scanned and analyzed with Image-J software ${ }^{[18]}$. In this study, anti-WNK1 and anti-WNK1 (phospho Thr58) antibodies were purchased from Abcam plc (Cambridge, UK) and the antibody against a-tubulin was purchased from Santa Cruz Biotechnology (Santa Cruz, CA, USA); cyclinD1, cyclinE1, p27 ${ }^{\mathrm{KIP}}$, Akt, phospho-AKT (Ser473), total PI3K, phospho-PI3K (Tyr458), and peroxidase-conjugated antibodies (HRP-linked) were purchased from Cell Signaling Technology, Inc (China). p21 ${ }^{\mathrm{CIP}}$ was from Millipore (Darmstadt, Germany).

\section{Proliferation assay}

Cell proliferation was assessed by 5-bromo-2'-deoxyuridine (BrdU) incorporation as we reported previously ${ }^{[7]}$. For the cell counts, A10 cells were trypsinized and plated into 96-well cul- 
ture plates at a density of $1 \times 10^{5}-1.5 \times 10^{5}$ cells in DMEM/F-12 supplemented with $10 \%$ NCS . After $24 \mathrm{~h}$, cells were rendered quiescent in $0.5 \%$ NCS for $24 \mathrm{~h}$ before the addition of fresh growth medium containing the appropriate supplements. The cell number was determined in triplicate using a hemocytometer. After transfection with WNK1 cDNA or siRNA, A10 cells were cultured under hypotonic conditions for $48 \mathrm{~h}$. DNA synthesis was assessed by BrdU incorporation. Cells were treated with the same supplements used in the cell count experiment before adding $10 \mathrm{mmol} / \mathrm{L}$ BrdU to the medium; 18 $\mathrm{h}$ later, cells were fixed and treated with anti-BrdU POD for 1 $h$ at room temperature. The antibody conjugate was removed by washing cells three times with 200-300 $\mu \mathrm{L} /$ well of washing solution. A total of $100 \mu \mathrm{L}$ of substrate solution was added to each well, cells were incubated for $10 \mathrm{~min}$ and then $25 \mu \mathrm{L} /$ well of $1 \mathrm{~mol} / \mathrm{L} \mathrm{H}_{2} \mathrm{SO}_{4}$ was added. The incorporation was measured at $450 \mathrm{~nm}$ on an ELISA microplate reader (BIO-TEK synergyHT, American $)^{[19]}$.

\section{Flow cytometry for cell cycle analysis}

The cell cycle status was evaluated by flow cytometry as described previously ${ }^{[20]}$. Briefly, A10 VSMCs were cultured in 35-mm culture plates, and then prk5-hWNK1 cDNA or WNK1 siRNA were transfected into cells, followed by incubation in hypotonic medium for $48 \mathrm{~h}$. A10 VSMCs were then collected by trypsin digestion and centrifugation at $200 \times \mathrm{g}$ for $5 \mathrm{~min}$ at $4{ }^{\circ} \mathrm{C}$. Granules were washed once with ice-cold phosphatebuffered saline (PBS) and fixed in 70\% ethanol for $24 \mathrm{~h}$. Samples were then stained with staining buffer (PBS containing 50 $\mu \mathrm{g} / \mathrm{mL}$ propidium iodide, $10 \mu \mathrm{g} / \mathrm{mL}$ RNase A, $0.1 \%$ sodium citrate and 0.1 Triton X-100). The DNA content was analyzed by flow cytometry (EPICS XL, Beckman Coulter, Miami, FL, USA) to reveal the population fraction in each phase of the cell cycle. Propidium iodide uptake was determined using fluorescence activated cell sorting.

\section{Statistical analysis}

All data are represented as the mean \pm SEM. Statistical significance was tested by Student's $t$-test or one-way analysis of variance followed by Duncan's multiple range tests. $P<0.05$ was considered significant.

\section{Results}

\section{Hypotonic solution evoked phosphorylation of WNK1}

As shown in Figure 1A, the Western blot results demonstrated that endogenous WNK1 was expressed in A10 VSMCs. When exposed to hypotonic challenge, WNK1 was significantly phosphorylated within $0.5 \mathrm{~min}$ and phosphorylation reached a maximum within $1 \mathrm{~min}$. The WNK1 phosphorylation level increased from $1.01 \pm 0.02$ to $1.39 \pm 0.05$ in $0.5 \mathrm{~min}$ and reached a maximum of $1.60 \pm 0.09$ in $1 \mathrm{~min}(P<0.01$ vs isotonic group, $n=6)$. However, the hypotonic solution did not alter WNK1 protein expression (Figure 1B). The hypertonic solution did not induce the phosphorylation of WNK1 or change WNK1 expression (Figure 1C, D).

\section{Effect of WNK1 on hypotonic-induced proliferation}

As the previous study shown, the hypotonic solution evoked proliferation in VSMCs ${ }^{[7]}$. In addition, as shown above, after exposure to the hypotonic solution, WNK1 was significantly phosphorylated. These results urged us to examine whether WNK1 exerts an effect on hypotonic-induced proliferation in A10 VSMCs. Our result demonstrated that overexpression of hWNK1 further increased proliferation induced by hypotonic challenge from $121.94 \% \pm 3.90 \%$ to $137.92 \% \pm 3.44 \% \quad(n=6$; $P<0.05$ vs vector; Figure $2 \mathrm{C}$ ). By contrast, silencing of WNK1 by siRNA significantly reduced hypotonic proliferation from $130.84 \% \pm 4.62 \%$ to $107.61 \% \pm 2.99 \% \quad(n=6 ; P<0.01$ vs negative control; Figure 2D). Cell proliferation was not changed in the vector and negative control groups.

\section{Influence of the T60A mutation on proliferation and WNK1 phosphorylation}

It was suggested that tyrosin 60 in hWNK1 was the functional phosphorylation site, which was the same as T58 of rat $W N K 1^{[17]}$. In order to further confirm VRCC-induced cell proliferation through WNK1 phosphorylation, we examined whether the T60A mutation could influence WNK1 phosphorylation and cell proliferation. As shown in Figure 3, overexpression of hWNK1 (T60A) increased protein expression to $2.24 \pm 0.45$ ( $P<0.05$ vs isotonic; $n=5)$. However, it did not further increase the WNK1 phosphorylation level induced by the hypotonic solution. The WNK1 phosphorylation levels in the control, vector and T60A groups were 1.71 $\pm 0.15,1.76 \pm 0.14$ and $1.72 \pm 0.18$, respectively $(P<0.05 ; n=4)$. Additionally, overexpression of hWNK1 (T60A) did not further accelerate hypotonic cell proliferation. Hypotonic-induced proliferation in the control, vector and T60A groups was $150.64 \% \pm 6.66 \%, 152.38 \%$ $\pm 7.91 \%$ and $153.23 \% \pm 8.50 \%$, respectively $(P>0.05 ; n=6)$.

Effect of WNK1 on the cell cycle in hypotonic challenged A10 cells As shown in Figure 4, hypotonic challenge promoted cell cycle transition from $\mathrm{G}_{0} / \mathrm{G}_{1}$ phase to $S$ phase. The hypotonic solution decreased the percentage of cells in $\mathrm{G}_{0} / \mathrm{G}_{1}$ phase from $84.35 \% \pm 1.22 \%$ to $71.91 \% \pm 1.83 \%$, and increased the percentage of cells in S phase from $8.80 \% \pm 0.94 \%$ to $23.17 \% \pm 1.85 \%$. Overexpression of WNK1 accelerated the effect of the hypotonic solution on cell cycle transition. The percentage of cells in $\mathrm{G}_{0} / \mathrm{G}_{1}$ phase was further decreased from $71.91 \% \pm 1.83 \%$ to $55.10 \% \pm 1.02 \%$, and the percentage of cells in S phase was further elevated from $23.17 \% \pm 1.85 \%$ to $32.66 \% \pm 0.98 \%(P<0.05$ vs hypotonic group; $n=7$; Figure $4 \mathrm{~A}$ ). By contrast, silencing of WNK1 decreased the effect of the hypotonic solution on cell cycle transition. The percentage of cells in $\mathrm{G}_{0} / \mathrm{G}_{1}$ phase was further increased from $66.81 \% \pm 1.32 \%$ to $81.25 \% \pm 1.46 \%$, and the percentage of cells in $S$ phase was significantly decreased from $25.32 \% \pm 2.43 \%$ to $13.11 \% \pm 1.88 \%$ ( $P<0.01$ vs hypotonic group; $n=7$; Figure 4B).

\section{Effects of WNK1 on cell cycle regulators}

Cell cycle transition from $G_{0} / G_{1}$ phase to $S$ phase is positively 
A
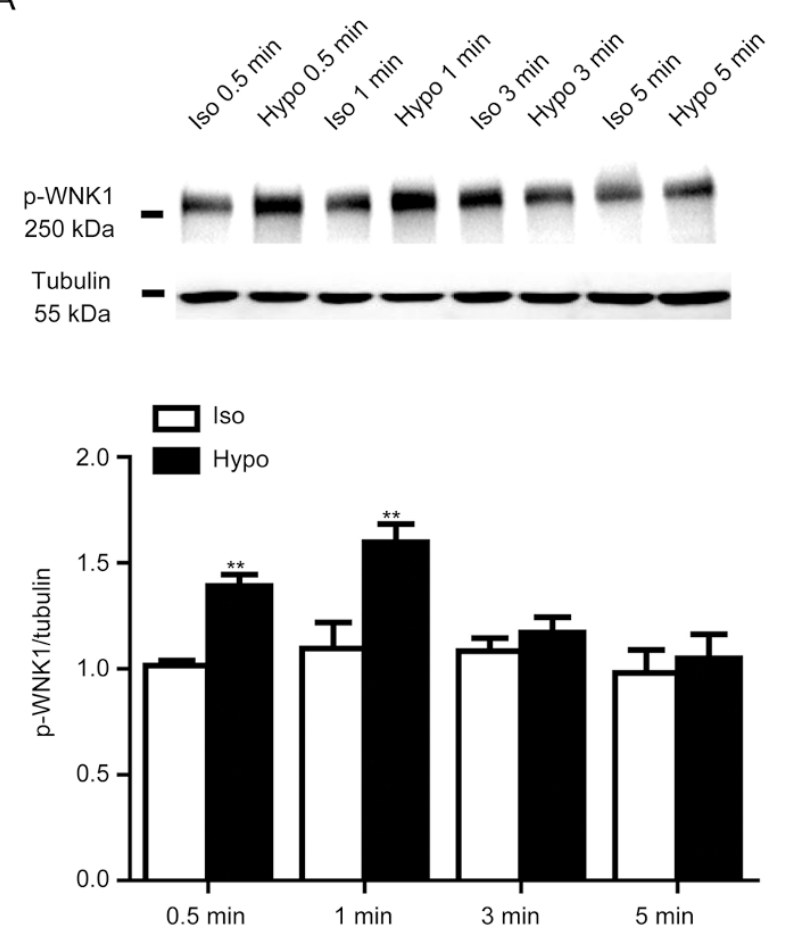

C
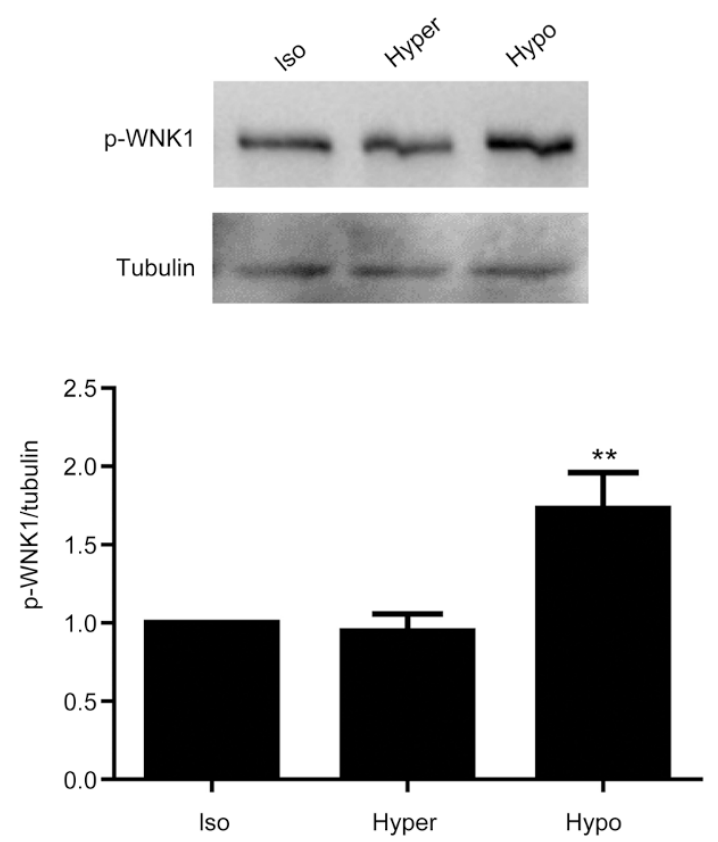

B
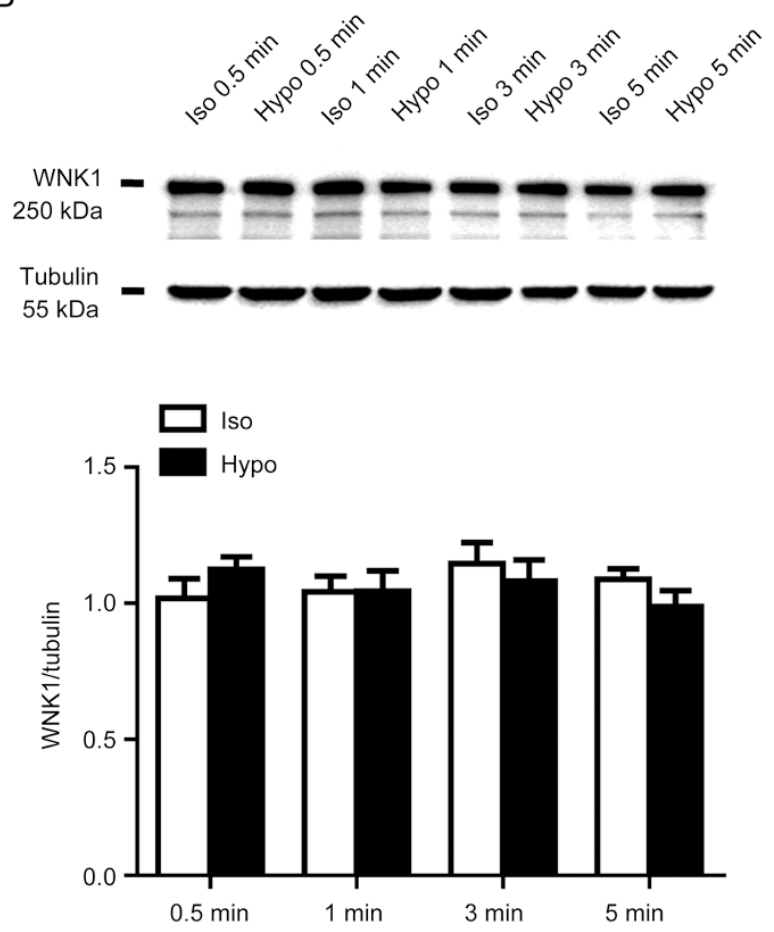

D
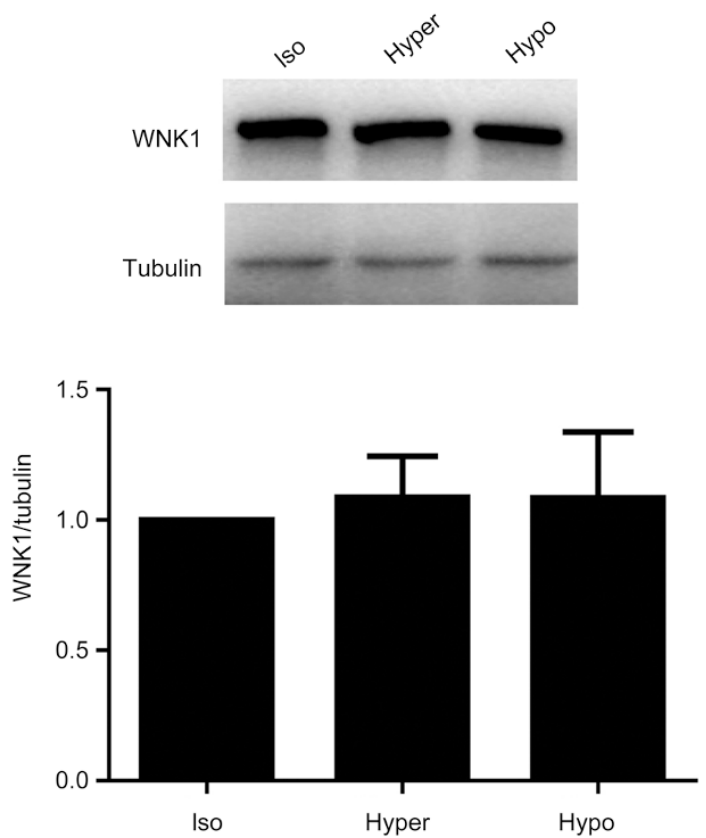

Figure 1. Hypotonic challenge evoked WNK1 phosphorylation. (A) WNK1 (T58) phosphorylation (p-WNK1) was evoked by hypotonic solution exposure from 0.5 to $3 \mathrm{~min}$. The hypotonic solution noticeably increased the WNK1 phosphorylation level within $0.5 \mathrm{~min}$ from $1.01 \pm 0.02$ to $1.39 \pm 0.05$ and up to $1.60 \pm 0.09$ in $1 \mathrm{~min}\left({ }^{* *} P<0.01\right.$ vs isotonic group. Mean \pm SEM. $\left.n=6\right)$. A representative Western blot and densitometric analysis of $p-W N K 1$ are shown. (B) Expression of WNK1 protein induced by the hypotonic solution. Densitometric analysis revealed that the hypotonic solution did not change WNK1 protein expression $(P>0.05$ vs isotonic group. Mean \pm SEM. $n=5)$. (C and D) Compared with the isotonic solution, the hypertonic solution did not alter the $p$-WNK1 and WNK1 expression levels, whereas the hypotonic solution enhanced the p-WNK1 level $\left({ }^{* *} P<0.01\right.$ vs Isotonic group. Mean $\pm S E M$. $\left.n=5\right)$. Abbreviations: Iso, isotonic solution; Hypo, hypotonic solution; hyper, hypertonic solution. 
A
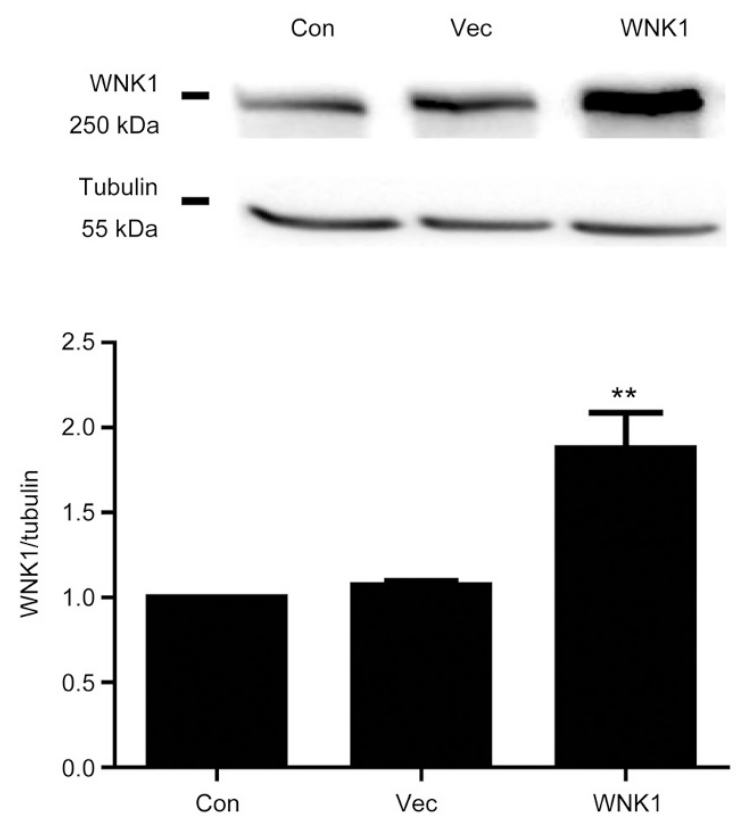

C

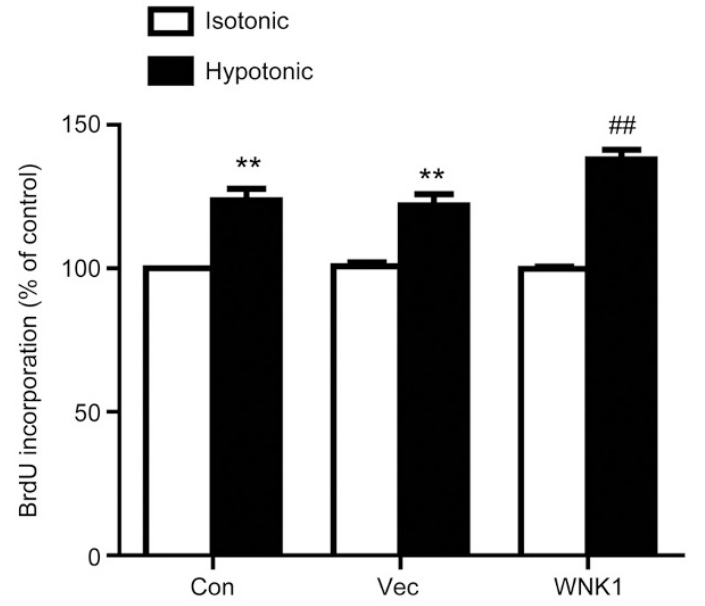

B
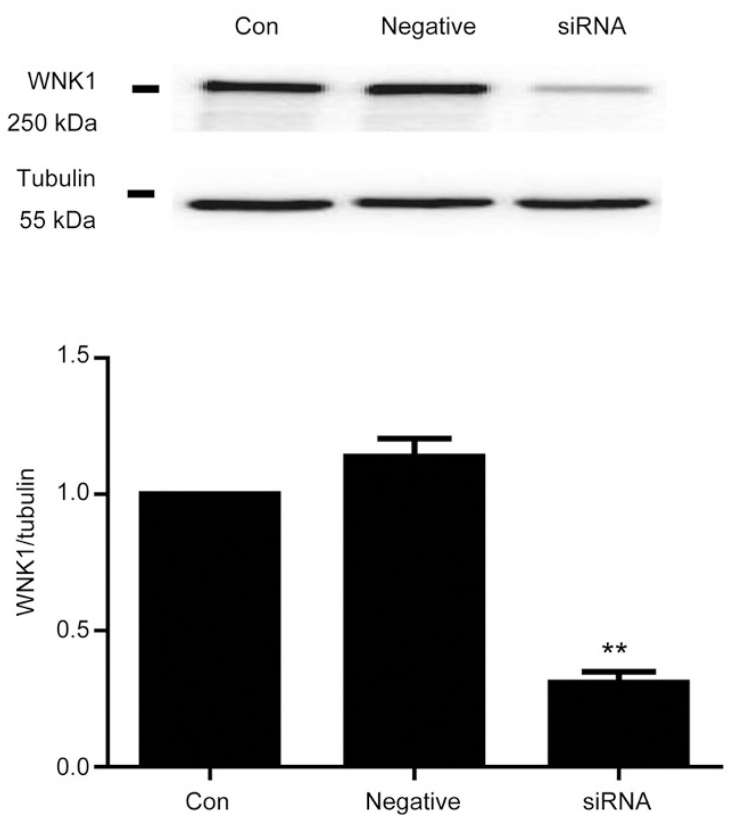

D

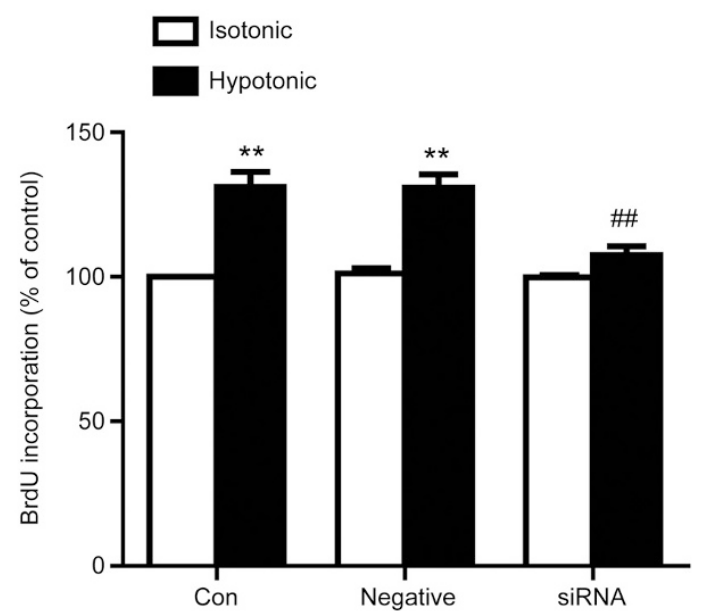

Figure 2. Effect of WNK1 on cell proliferation induced by the hypotonic solution. (A) Expression of WNK1 in hWNK1 cDNA transfected cells. A10 VSMCs were transfected with hWNK1 cDNA $(1 \mu \mathrm{g} / \mathrm{mL})$ for $48 \mathrm{~h}$. Expression of WNK1 was determined by Western blot. Densitometric analysis revealed that WNK1 expression was significantly increased from $1.07 \pm 0.03$ to $1.88 \pm 0.21\left({ }^{* *} P<0.01\right.$ vs vector group. Mean $\pm S E M$. $n=5$ ). (B) Expression of WNK1 in A10 VSMCs exposed to WNK1 siRNA at $20 \mathrm{nmol} / \mathrm{L}$ for $48 \mathrm{~h}$. Compared with the negative group, WNK1 expression was remarkably reduced from $1.14 \pm 0.07$ to $0.31 \pm 0.04\left({ }^{* *} P<0.01\right.$ vs negative siRNA group. Mean \pm SEM. $\left.n=4\right)$. (C) The hypotonic solution evoked cell proliferation by $123.67 \% \pm 4.03 \%$. Overexpression of WNK1 further increased hypotonic proliferation from $123.67 \% \pm 4.03 \%$ to $137.92 \% \pm 3.44 \%\left({ }^{* *} P<0.01\right.$ vs vector group in the isotonic group. ${ }^{\# \#} P<0.01$ vs vector in the hypotonic group. Mean \pm SEM. $n=6$ ). (D) Silencing of WNK1 reduced hypotonic proliferation to $107.61 \% \pm 2.98 \%$ ( ${ }^{\#} P<0.01$ vs negative siRNA in the hypotonic group. Mean \pm SEM. $n=6$ ).

regulated by cyclins and cyclin-dependent kinases, including cyclinD1 and cyclinE1, and negatively controlled by cyclindependent kinase inhibitors, including $\mathrm{p}^{\mathrm{CIP}}$ and $\mathrm{p} 27^{\mathrm{KIP}}$. As shown in Figure 5, the hypotonic solution increased cyclinD1 and cyclinE1 expression from $1.06 \pm 0.04$ and $1.01 \pm 0.06$ to $1.74 \pm 0.14$ and $1.67 \pm 0.14$, respectively $(P<0.01$, vs vector; $n=7)$ and inhibited $\mathrm{p} 21^{\mathrm{CIP}}$ and $\mathrm{p} 27^{\mathrm{KIP}}$ expression from $1.04 \pm 0.03$ and
$1.03 \pm 0.02$ to $0.64 \pm 0.06$ and $0.66 \pm 0.05$, respectively $(P<0.01$, vs vector; $n=6$ ). Overexpression of WNK1 further increased hypotonic-induced cyclinD1 and cyclinE1 expression to $2.46 \pm 0.25$ and $2.50 \pm 0.31$, respectively $(P<0.01$, vs vector; $n=7)$. By contrast, silencing of WNK1 decreased expression of cyclinD1 and cyclinE1 from $1.83 \pm 0.18$ and $1.99 \pm 0.25$ to $1.17 \pm$ 0.18 and $1.38 \pm 0.17$, respectively $(P<0.01$, $v$ s vector; $n=6)$. The 
A

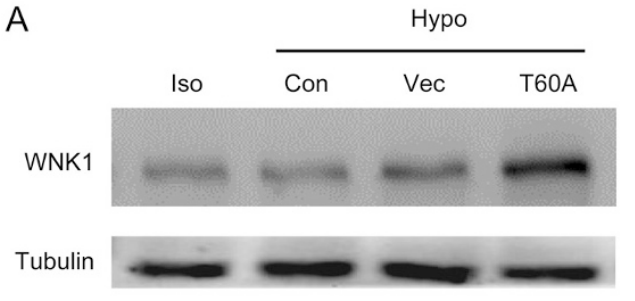

B

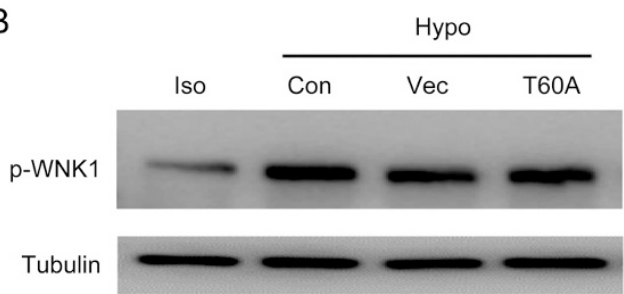

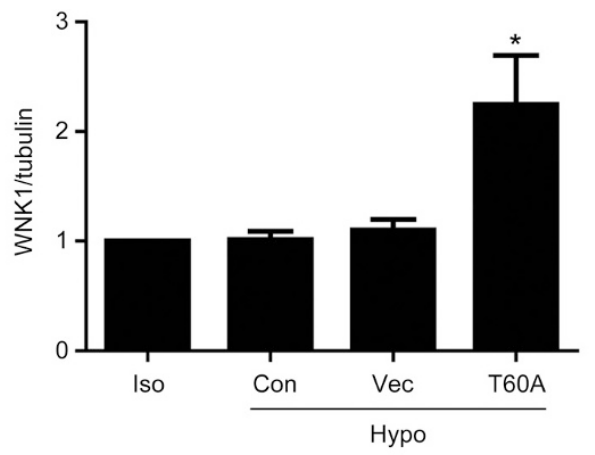
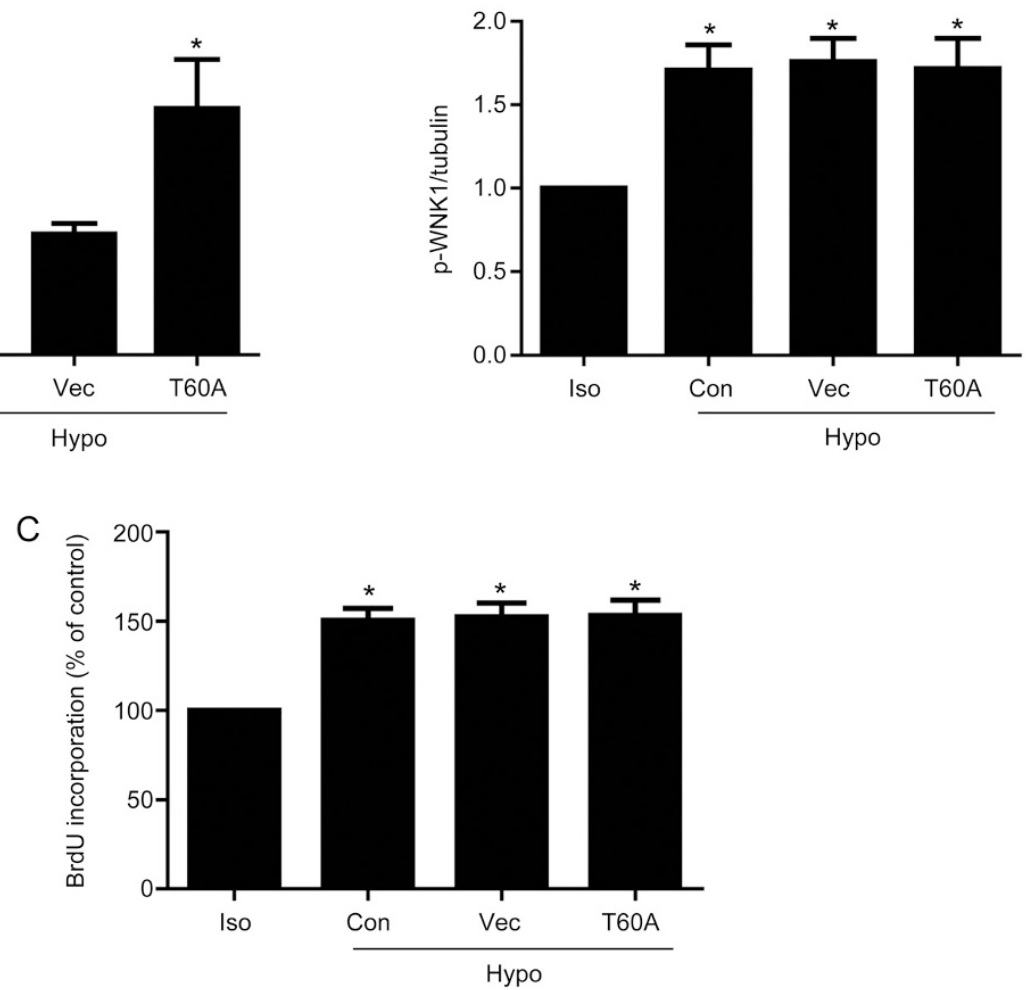

Figure 3. T60A mutation did not significantly influence hypotonic-induced phosphorylation and proliferation. (A) Western blot and densitometric analysis demonstrated that transfection of hWNK1 (T60A) increased WNK1 protein to $2.24 \pm 0.45\left({ }^{*} P<0.05\right.$ vs isotonic; $\left.n=5\right)$. (B) Hypotonic challenge for 1 min significantly increased WNK1 phosphorylation to $1.72 \pm 0.18$. Transfection of hWNK1(T60A) did not further increase the phosphorylation level under hypotonic conditions ( ${ }^{*} P<0.05$ vs isotonic. Mean \pm SEM. $\left.n=4\right)$. Representative Western blot and densitometric analysis of $p$-WNK1 level are shown. (C) BrdU incorporation revealed that the hypotonic solution increased cell proliferation to $150.64 \% \pm 6.66 \%$, which was not further enhanced by transfection with hWNK1(T60) (Mean \pm SEM. $n=6)$.

hypotonic inhibitory effects on the expression of $\mathrm{p} 21^{\mathrm{CIP}}$ and p2 $7^{\mathrm{KIP}}$ were reversed by silencing of WNK 1 from $0.66 \pm 0.07$ and $0.61 \pm 0.09$ to $0.98 \pm 0.07$ and $0.91 \pm 0.13$, respectively $(P<0.01$, vs vector; $n=7)$. In the isotonic solution, WNK1 did not influence the expression of any of the cell cycle factors.

\section{Effect of WNK1 on Akt phosphorylation}

Cell cycle factors are regulated by the Akt signaling pathway. Therefore, we determined whether WNK1 changes the expression of cell factors through the Akt pathway. As shown in Figure 6, overexpression of WNK1 accelerated Akt phosphorylation induced by the hypotonic solution from $1.74 \pm 0.15$ to $2.68 \pm 0.38$ (Figure $5 \mathrm{~A}, P<0.01$, vs vector; $n=6$ ). Hypotonicinduced Akt phosphorylation was inhibited by the silencing of WNK1 from $1.63 \pm 0.17$ to $1.19 \pm 0.13$ (Figure $6 \mathrm{C}, P<0.01$, vs vec- tor; $n=6)$. Neither knockdown nor overexpression of WNK1 altered Akt protein expression or the Akt phosphorylation level under isotonic conditions.

\section{Effects of WNK1 on PI3K-p85 phosphorylation}

As shown in Figure 7, hypotonic challenge for 1 min significantly increased PI3K p85 phosphorylation (p-PI3K) from $1.04 \pm 0.07$ to $1.70 \pm 0.13$ ( $P<0.01$ vs vector; $n=5)$.

Hypotonic-induced p-PI3K-p85 was further increased from $1.70 \pm 0.13$ to $2.11 \pm 0.14$ by the overexpression of WNK1 $(P<0.01$ vs vector group; $n=5)$. By contrast, silencing of $W N K 1$ reduced p-PI3K-p85 from $1.70 \pm 0.13$ to $1.18 \pm 0.16(P<0.01$ vs negative group; $n=5)$.

Under isotonic conditions, WNK1 did not influence the resting PI3K-p85 phosphorylation level or protein expression. 
A
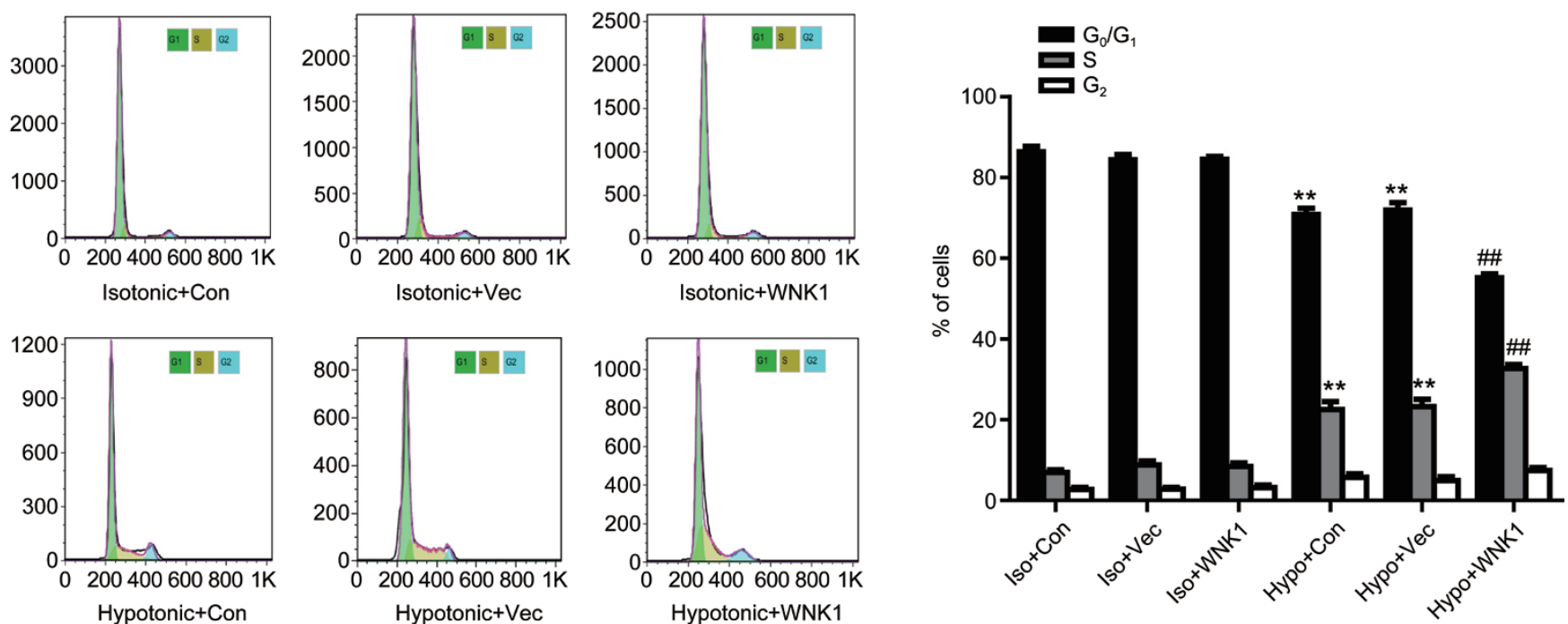

B
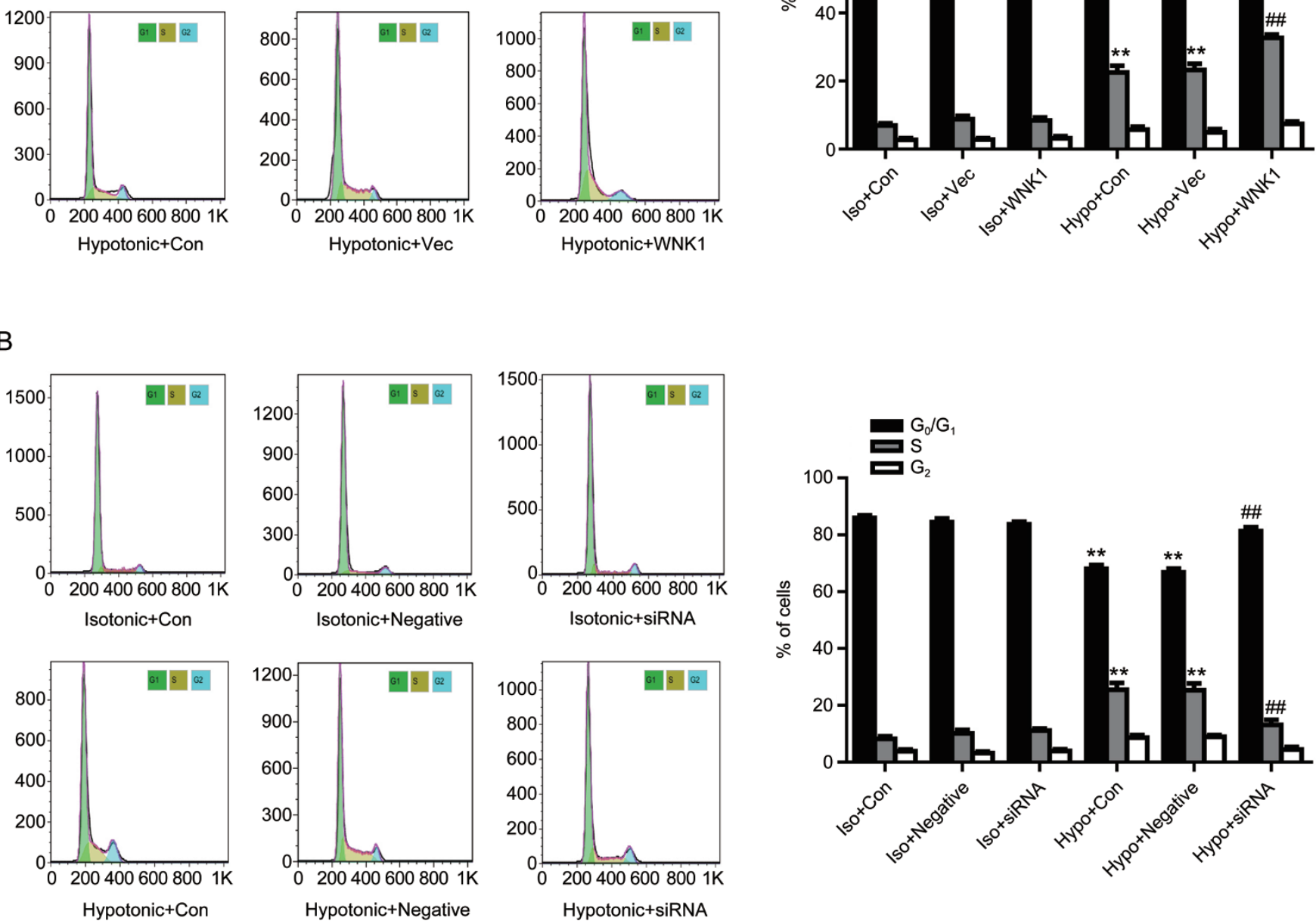

Figure 4. WNK1 enhanced cell cycle transition induced by the hypotonic solution. (A) Hypotonic-induced cell cycle transition was detected by flow cytometric analysis. Densitometric analysis demonstrated that the hypotonic solution accelerated cell cycle transition from $G_{0} / G_{1}$ phase to $S$ phase $\left({ }^{* *} P<0.01\right.$ vs vector in the isotonic group), which was further increased by overexpression of WNK1 (\#\# $P<0.01$ vs vector in the hypotonic group. Mean \pm SEM. $n=7)$. (B) Silencing of WNK1 by WNK1-siRNA transfection reduced the cell cycle transition induced by the hypotonic solution. $\left({ }^{* *} P<0.01\right.$ vS negative in the isotonic group. ${ }^{\# \#} P<0.01$ vs negative in the hypotonic group. Mean \pm SEM. $n=7$ )

\section{Discussion}

$\mathrm{Cl}^{-}$is a main anion in intracellular plasma. It mediates membrane potential, intracellular $\mathrm{pH}$, and cell growth, and also maintains the intracellular $\mathrm{pH}^{[10,21]}$. In most cells, although the extracellular $\mathrm{Cl}^{-}$concentration is $150 \mathrm{mmol} / \mathrm{L}$, the $\left[\mathrm{Cl}^{-}\right]_{\mathrm{i}}$ level is maintained at 30 to $60 \mathrm{mmol} / \mathrm{L}^{[16]}$. Based on the cal-

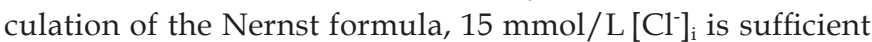
to maintain electrochemical equilibrium in VSMCs ${ }^{[22,23]}$. Thus, $\mathrm{Cl}^{-}$channel opening can lead to $\mathrm{Cl}^{-}$efflux and the decrease of $\left[\mathrm{Cl}^{-}\right]_{\mathrm{i}}$.

Our previous study showed that hypotonic challenge evoked VSMC proliferation through the activation of VRCC, resulting in $\mathrm{Cl}^{-}$efflux and the decrease of $\left[\mathrm{Cl}^{-}\right]_{i}^{[5-7]}$. However, it is not clear how VRCC-induced low $\left[\mathrm{Cl}^{-}\right]_{\mathrm{i}}$ gives rise to cell proliferation. Recently, many $\mathrm{Cl}^{-}$-binding and $\mathrm{Cl}^{-}$-regulated proteins have been shown to be associated with physiological and pathophysiological processes ${ }^{[10,24,25]}$. Therefore, we postulate that VRCC-induced low $\left[\mathrm{Cl}^{-}\right]_{\mathrm{i}}$ may activate one or 
A

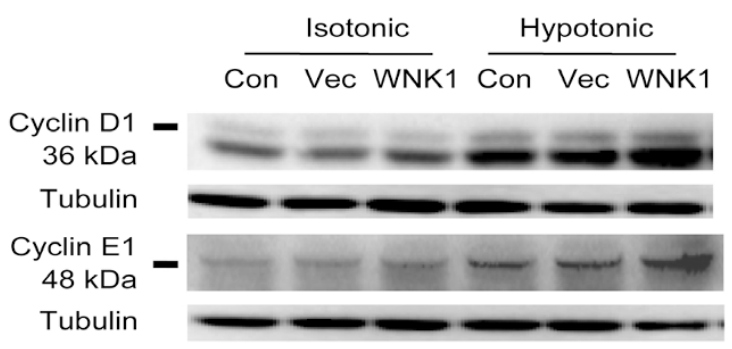

Cyclin D1

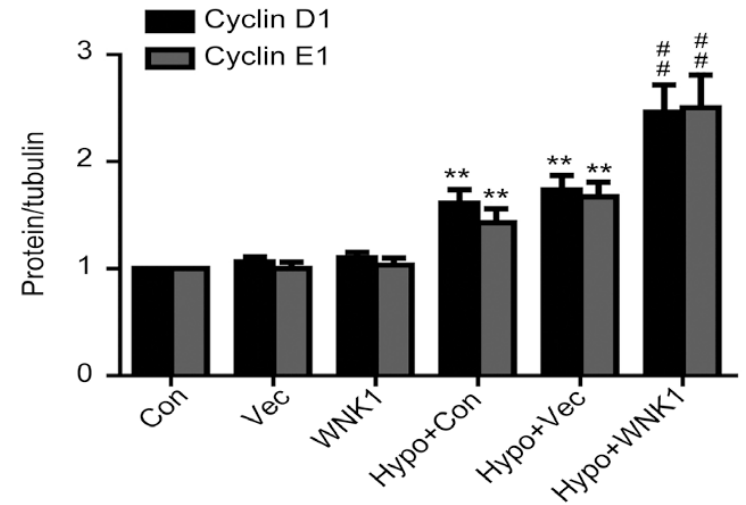

C
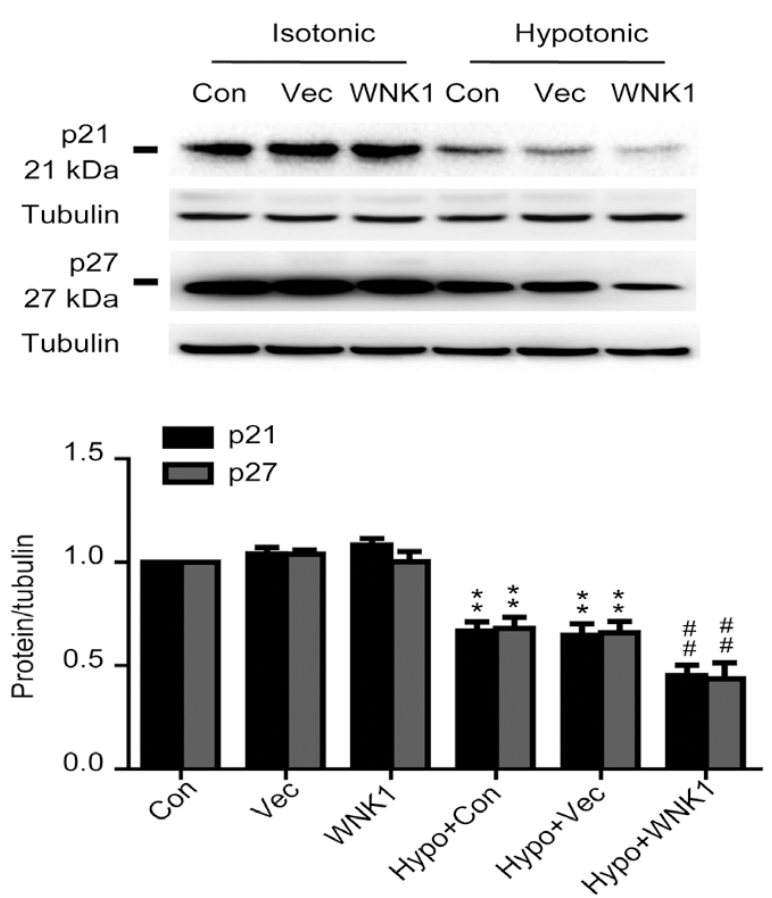

B

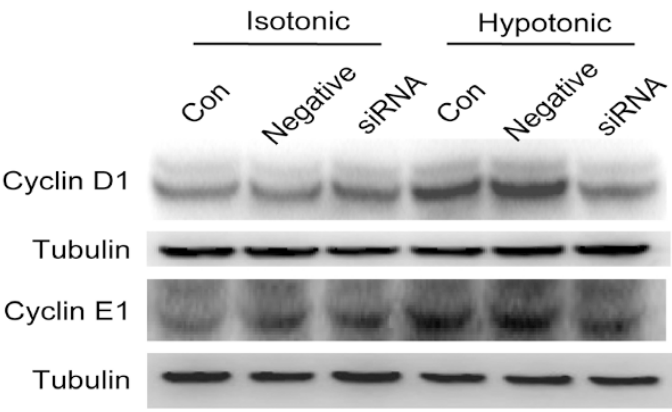

Cyclin D1

드리 E1

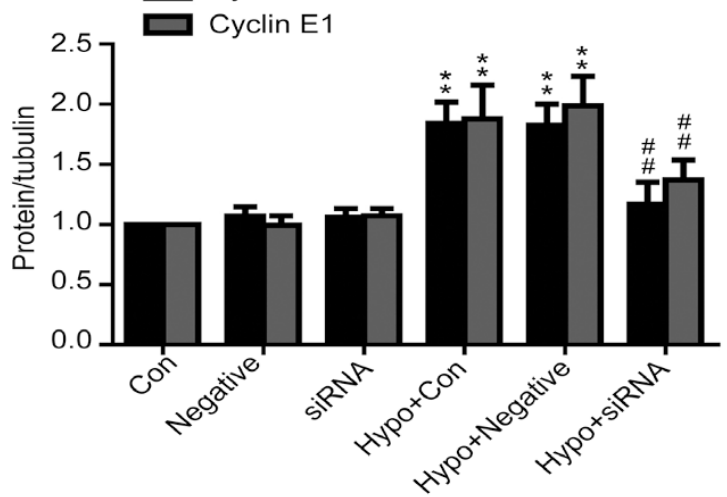

D
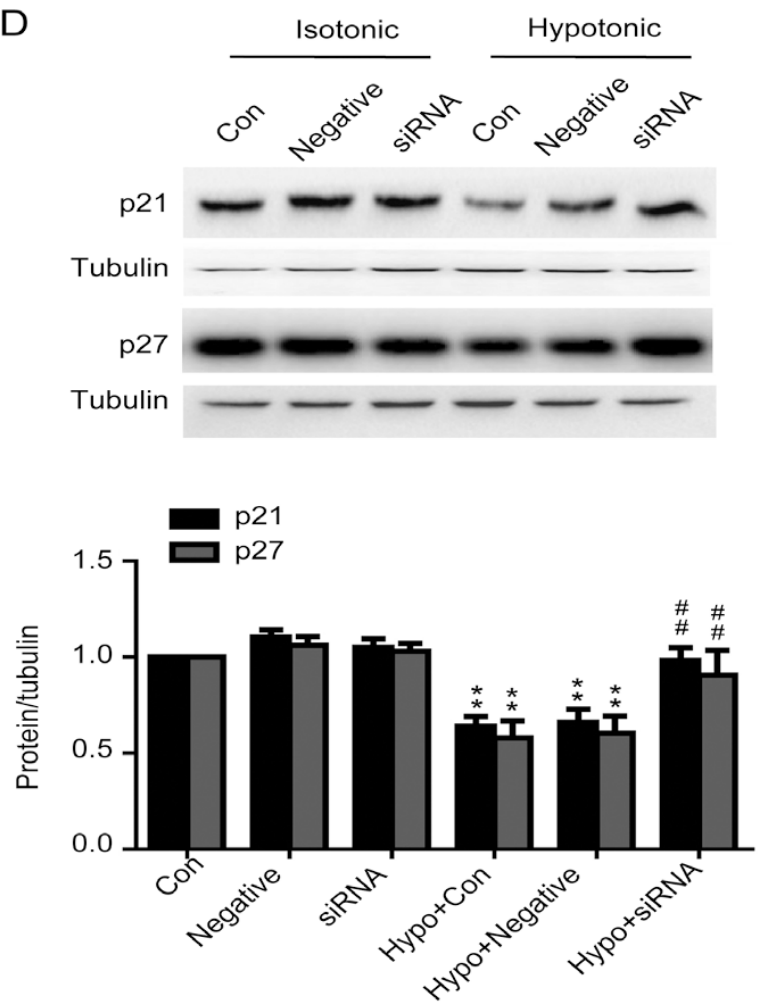

Figure 5. Effects of WNK1 on cell cycle regulatory proteins. (A, C) Overexpression of WNK1 enhanced the expression of cyclin D1 and cyclin E1, and reduced p21 and p27 expression induced by the hypotonic solution. (B, D) Silencing of WNK1 reduced cyclin D1 and cyclin E1 expression and increased $\mathrm{p} 21^{\mathrm{CIP}}$ and $\mathrm{p} 27^{\mathrm{KIP}}$ expression. $n=6-7$. Mean \pm SEM. ${ }^{* *} \mathrm{P}<0.01$ vs vector in the isotonic group. ${ }^{\# \#} P<0.01$ vs vector in the hypotonic group. 
A
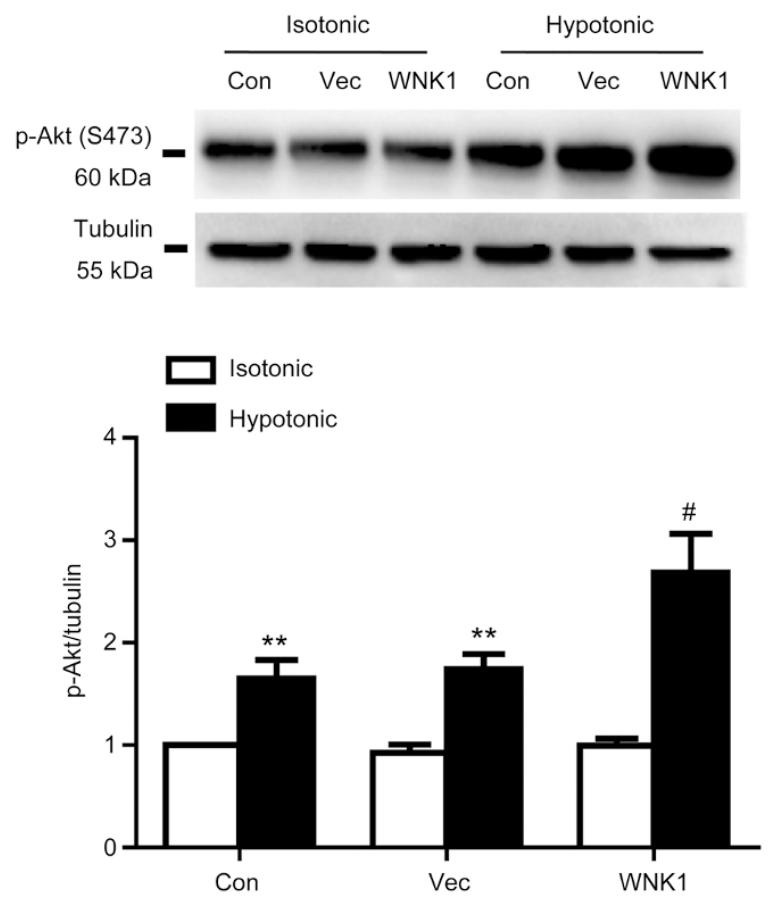

C
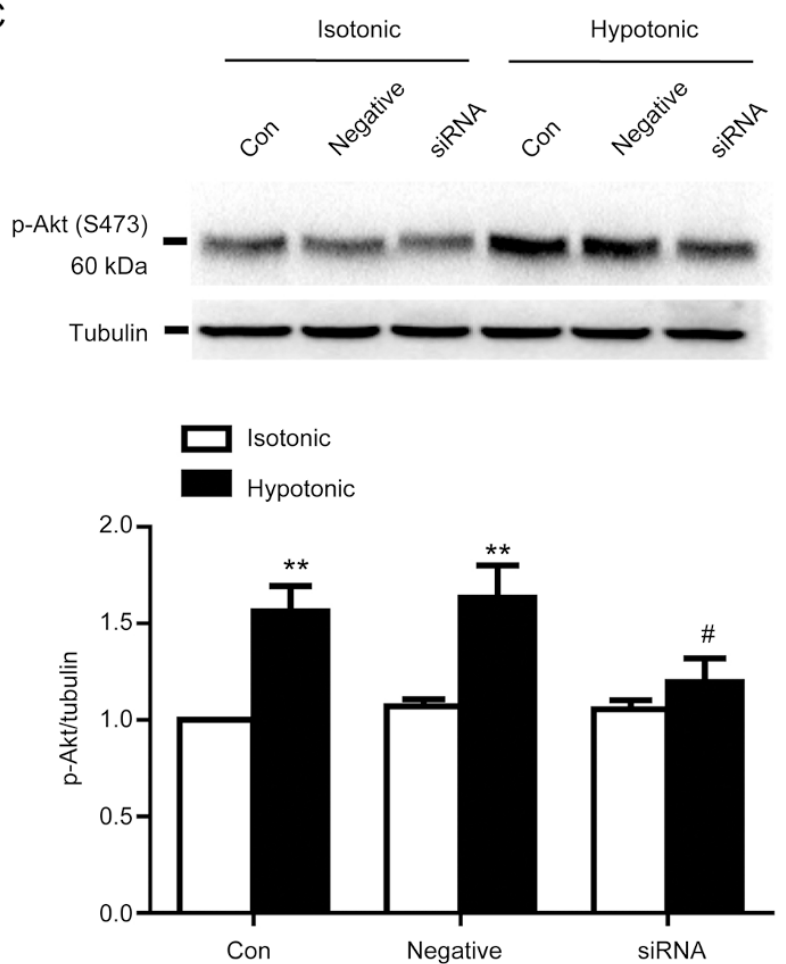

B
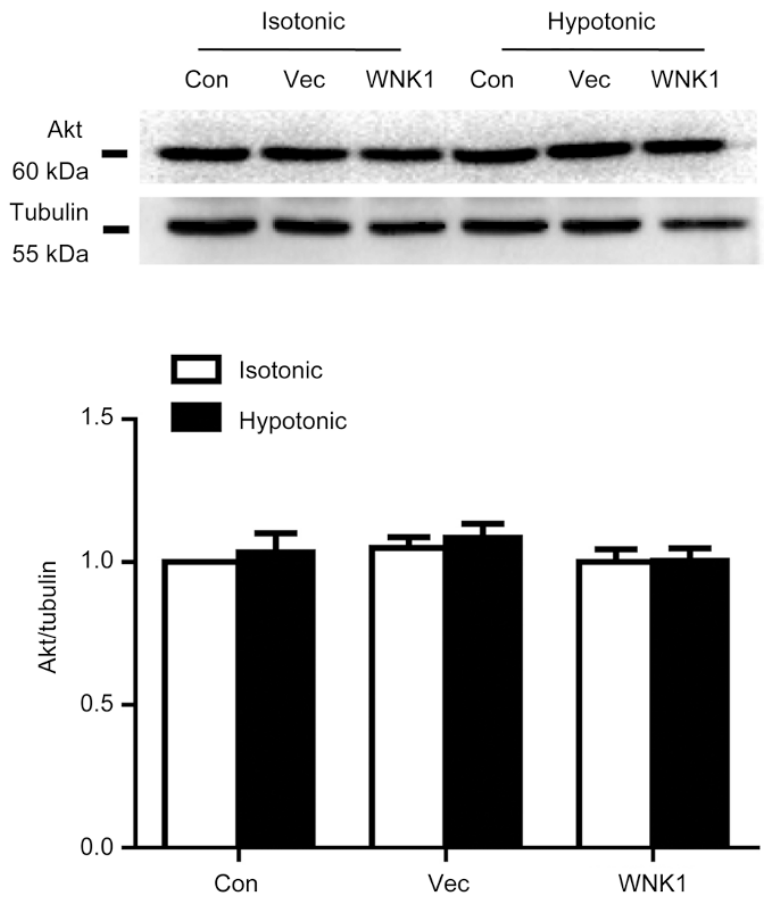

D
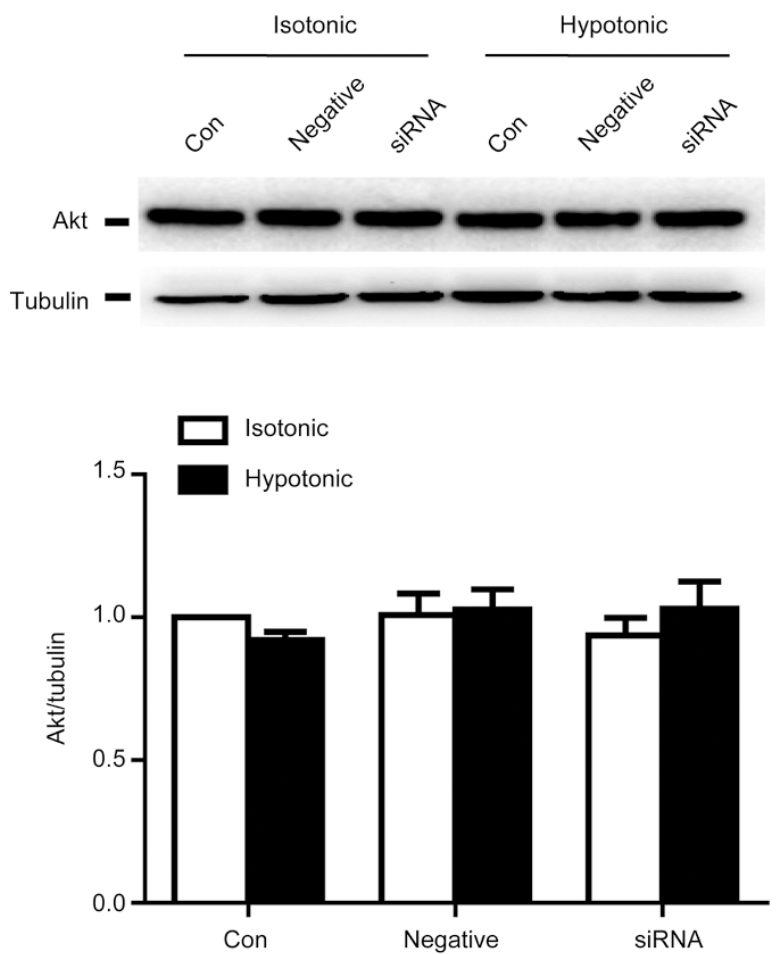

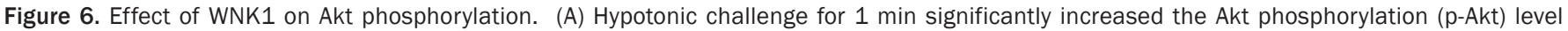

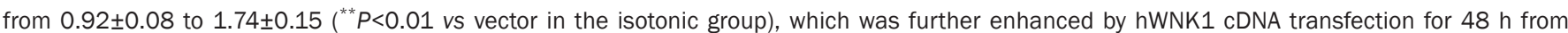

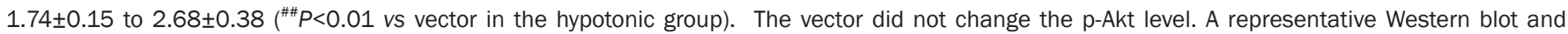

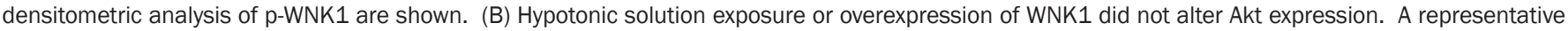

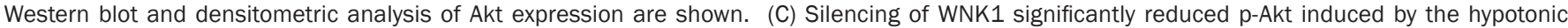

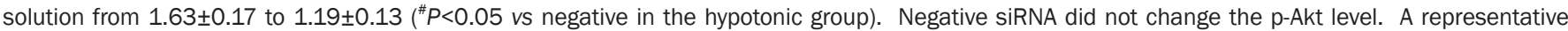

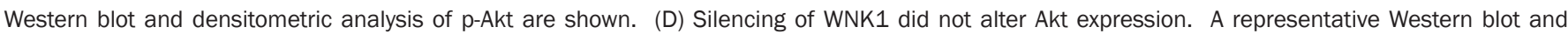
densitometric analysis of Akt expression are shown. Mean \pm SEM. $n=6$. 
A
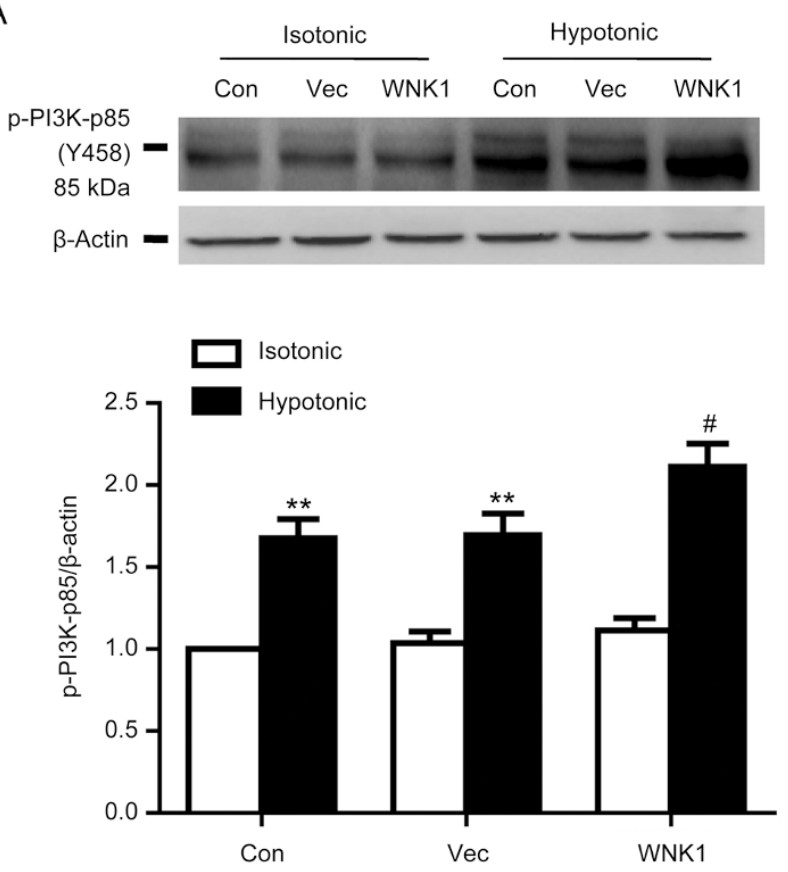

C
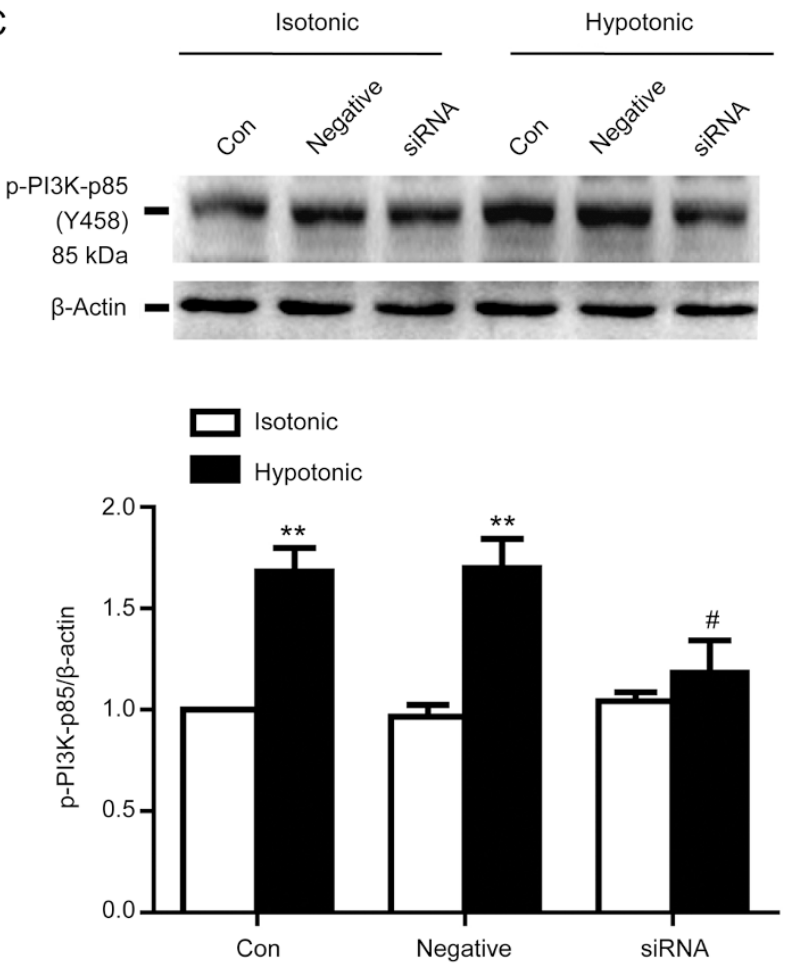

B
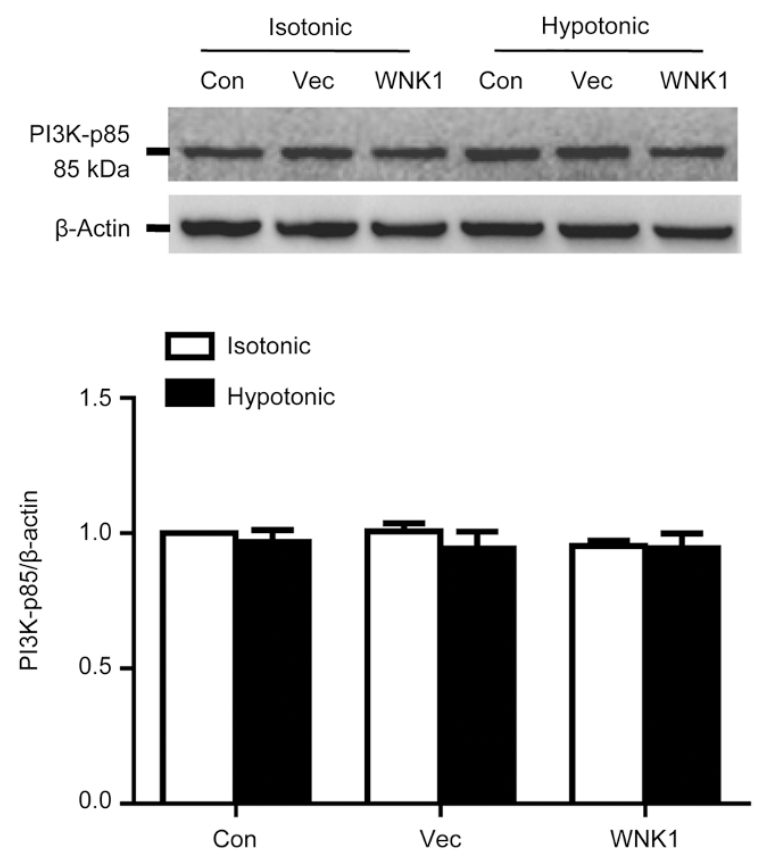

D
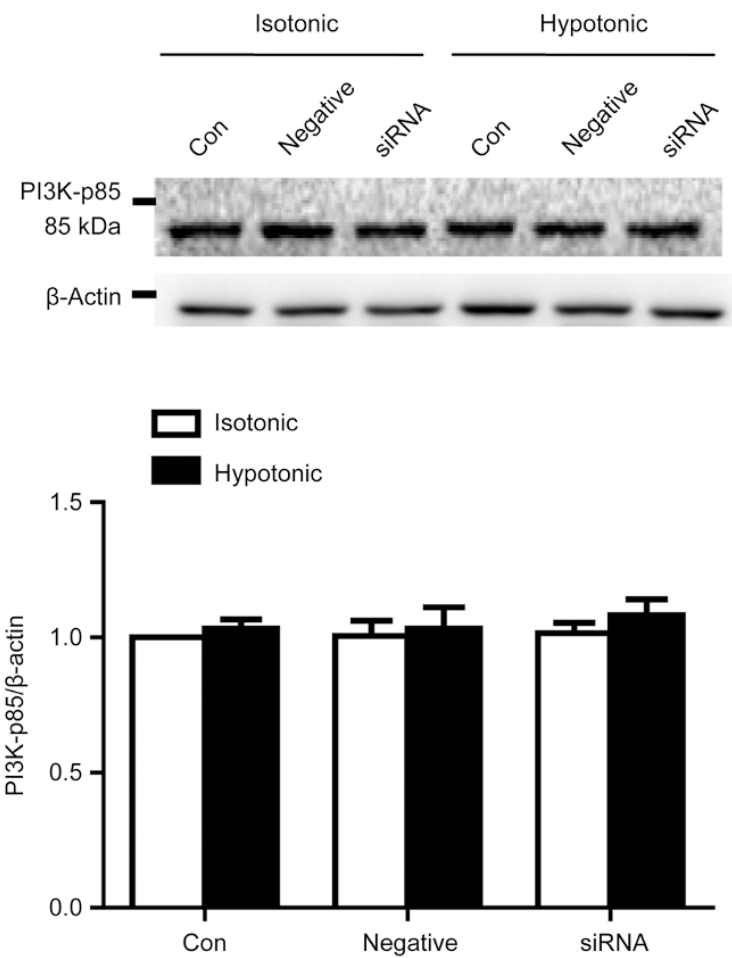

Figure 7. Effects of WNK1 on PI3K phosphorylation and expression. (A) Hypotonic challenge for 1 min significantly increased PI3K-p85 phosphorylation (p-PI3K) from $1.04 \pm 0.07$ to $1.70 \pm 0.13\left({ }^{* *} P<0.01\right.$ vs vector in the isotonic group; $\left.n=5\right)$. Overexpression of WNK1 further increased $p$-PI3K to $2.11 \pm 0.14(" P<0.05$ vs vector in the hypotonic group; $n=5)$. Treatment with the vector did not influence the p-PI3K level. A representative Western blot and densitometric analysis of p-PI3K level are shown. (B) Western blot and densitometric analysis demonstrated that both exposure to the hypotonic solution and overexpression of WNK1 did not alter PI3K p-85 protein expression. (C) Silencing of WNK1 by transfection with WNK1 siRNA for $48 \mathrm{~h}$ remarkably reduced the increase in $\mathrm{p}-\mathrm{PI} 3 \mathrm{~K}$ induced by the hypotonic solution treatment from $1.70 \pm 0.13$ to $1.18 \pm 0.16$ ( $P<0.05 \mathrm{vs}$ negative in the hypotonic group; $n=5$ ). Negative siRNA did not change the increase of the p-PI3K level induced by the hypotonic solution. Western blot and densitometric analysis of p-PI3K are shown. (D) Western blot and densitometric analysis demonstrated that neither the hypotonic solution nor the silencing of WNK1 altered PI3K p-85 protein expression. Mean \pm SEM. 
more $\mathrm{Cl}^{-}$sensitive kinases, resulting in a subsequent signaling cascade. WNKs are part of a large family of serine/threonine protein kinases that contains four members: WNK1-4. WNK1 is widely expressed in diverse tissues and cells, with the highest levels found in the testis, heart, kidney, skeletal muscle and VSMCs. WNK1 is characterized by autophosphorylation. When $\mathrm{Cl}^{-}$directly binds to the catalytic site of WNK1, WNK1 is in an inactive state due to the blockade of autophosphorylation $^{[16,26]}$. It has been revealed that WNK1 regulates vasoconstriction in response to a1-adrenergic stimulation, suggesting that WNK1 mediates a vascular signaling pathway ${ }^{[27]}$. In this study, we first demonstrated that WNK1 was endogenously expressed in A10 VSMCs and that a hypotonic challenge could evoke WNK1 phosphorylation without any alteration in WNK1 expression. The hypertonic solution did not evoke WNK1 phosphorylation. In our previous study, it was revealed that hypotonic challenge, but not hypertonic challenge, reduced $\left[\mathrm{Cl}^{-}\right]_{i}{ }^{[5-7]}$. These results suggested that VRCC-induced low $\left[\mathrm{Cl}^{-}\right]_{\mathrm{i}}$ can evoke WNK1 phosphorylation in A10 cells. If it is true that VRCC-induced low $\left[\mathrm{Cl}^{-}\right]_{\mathrm{i}}$ activates WNK1 by removing the autophosphorylation blockade, activated WNK1 should be involved via a signaling cascade that eventually leads to cell proliferation. Therefore, we determined whether WNK1 is involved in vascular cell cycle transition and proliferation induced by hypotonic solution. It was found that hypotonic challenge led to cell cycle transition from $\mathrm{G}_{0} / \mathrm{G}_{1}$ to $S$ phase and to cell proliferation. These responses to the hypotonic solution were further enhanced by the overexpression of WNK1 and reduced by silencing of WNK1. Furthermore, WNK1 mutation did not affect phosphorylation and cell proliferation. This finding indicates that WNK1 is involved in hypotonic challenge-induced cell cycle transition and proliferation. Cell cycle transition from $\mathrm{G}_{0} / \mathrm{G}_{1}$ to $S$ phase is regulated by cell cycle factors. Third, our results further showed that the hypotonic solution increased cyclin D1 and cyclin E1 expression and inhibited the expression of $\mathrm{p} 21^{\mathrm{CIP}}$ and $\mathrm{p} 27^{\mathrm{KIP}}$. These hypotonic effects were strengthened by WNK1 overexpression and diminished by silencing of WNK1, indicating that these hypotonic effects on cell cycle factors were dependent on WNK1. It is known that VRCC activates the PI3K-Akt signaling pathway, which mediates cell cycle $\mathrm{G}_{1}$ / $S$ transition by influencing the expression of cell cycle factors $^{[20]}$. Finally, we determined the role of WNK1 in the PI3KAkt signaling pathway activated by the hypotonic solution. Hypotonic solution-induced phosphorylation of Akt and PI3K was further increased by WNK1 overexpression and inhibited by silencing of WNK1. The results revealed that WNK1 mediated activation of the PI3K-Akt signaling pathway, which was induced by VRCC.

Altogether, these data indicate that hypotonic challenge activates VRCC, leading to $\mathrm{Cl}^{-}$efflux and to a decrease in $\left[\mathrm{Cl}^{-}\right]_{\mathrm{i}}$ in A10 VSMCs. WNK1 is phosphorylated, resulting in cell cycle transition from $G_{0} / G_{1}$ to $S$ phase and proliferation through the PI3K-Akt signaling pathway.

We noted the different reports in which the decrease in intracellular $\mathrm{Cl}^{-}$concentration induced by a low chloride medium inhibited cell cycle transition from $G_{0} / G_{1}$ to $S$ phase, as well as cell growth through the activation of the p38 and/ or JNK cascades and the diminution of CDK2 and phosphorylated $\mathrm{Rb}$ in human gastric cancer cells ${ }^{[28]}$. This discrepancy may arise from the different manner of induction of low $\left[\mathrm{Cl}^{-}\right]_{\mathrm{i}}$. Our previous study showed that although VRCC and the $\mathrm{Ca}^{2+}$ activated $\mathrm{Cl}^{-}$channel, which are two different $\mathrm{Cl}^{-}$channels, could cause $\mathrm{Cl}^{-}$efflux and low $\left[\mathrm{Cl}^{-}\right]_{\mathrm{i}}$, VRCC evoked proliferation and the $\mathrm{Ca}^{2+}$-activated $\mathrm{Cl}^{-}$channel inhibited proliferation induced by angiotensin II in VSMCs ${ }^{[6,18]}$. The responses to low $\left[\mathrm{Cl}^{-}\right]_{\mathrm{i}}$ may be involved in many signaling pathways. Low $\mathrm{Cl}^{-}$ medium promoted endothelial cell inflammation by activating the nuclear factor- $\mathrm{kB}$ pathway ${ }^{[9]}$, and foam cell formation by low $\mathrm{Cl}^{-}$medium was mediated by activation of JNK and the p38 mutagen-activated protein kinesis pathway ${ }^{[29]}$. Therefore, another possibility is that the signaling pathways involved in low $\left[\mathrm{Cl}^{-}\right]_{\mathrm{i}}$ are various because of the cell type or tissue properties.

Additionally, we noted that WNK1 was activated by hypertonic stress in kidney epithelial cells, as well as breast and colon cancer cell lines ${ }^{[30]}$. WNK1 is clustered into a tetramer in these cells and kept inactive. Within the tetramer, one WNK1 autophosphorylation domain may depress WNK1 activity ${ }^{[31]}$. Thus, hypertonic stress may induce a conformational change of WNK1 from a tetramer to a monomer, leading to WNK1 activation. Another possibility is that hypertonic stress accelerates WNK1 interactions with other kinases and leads to activation. Hypertonic stress leads to the physical interaction of germinal center kinases with WNK1, resulting in the two kinases functioning together in a common signaling cascade ${ }^{[32]}$. Therefore, these findings indicate that WNK1 phosphorylation induced by hypertonic stress is not related to the alteration of $\left[\mathrm{Cl}^{-}\right]_{\mathrm{i}}$ because the current results and our previous data demonstrate that hypertonic stress does not change the $\left[\mathrm{Cl}^{-}\right]_{\mathrm{i}}$ level ${ }^{[5-7]}$ and induces WNK1 phosphorylation.

It is well known that VSMC proliferation is required for the progression of atherosclerosis, hypertension and vascular remodeling. Our present results suggest that vascular proliferation can be inhibited through the blockage of WNK1 phosphorylation. In addition, recently, we found that the WNK1 phosphorylation level was significantly increased in the basilar artery in angiotensin II-induced cerebrovascular remodeling mice (unpublished data). Thus, WNK1, as a new target, may provide a new strategy for the treatment of proliferative vascular diseases.

In summary, the present study demonstrates that VRCC activation by hypotonic challenge induces $\mathrm{Cl}^{-}$efflux and a decrease in $\left[\mathrm{Cl}^{-}\right]_{\mathrm{i}}$, resulting in WNK1 phosphorylation. Activated WNK1 mediates cell cycle transition from $G_{0} / G_{1}$ to $S$ phase and proliferation through the PI3K-Akt signaling pathway in A10 VSMCs. Therefore, our results may shed new light on the understanding that WNK1, as a cytoplasmic second messenger, is involved in a $\mathrm{Cl}^{-}$channel-induced signaling cascade, and these findings provide a new strategy for the 
treatment of proliferative vascular diseases.

\section{Acknowledgements}

This work was supported by the National Natural Science Foundation of China (№ 81230082, 81173055, 81302771, 81370897). Thanks to Dr SHIBUYA in the Medical Research Institute, Tokyo Medical and Dental University for kindly providing the prk5WNK1 cDNA plasmid.

\section{Author contribution}

Ya-Juan ZHANG and Hua-qing ZHENG performed experiments, acquired and analyzed the data; Bao-yi CHEN and Lu SUN performed some experiments; Ming-ming MA and Guan-lei WANG analyzed and interpreted the data and performed statistical analysis; and Yong-yuan GUAN conceived and designed the research and wrote the manuscript.

\section{References}

1 Lang F, Ritter M, Gamper N, Huber S, Fillon S, Tanneur V, et al. Cell volume in the regulation of cell proliferation and apoptotic cell death. Cell Physiol Biochem 2000; 10: 417-28.

2 Hoffmann EK, Lambert IH, Pedersen SF. Physiology of cell volume regulation in vertebrates. Physiol Rev 2009; 89: 193-277.

3 Eggermont J, Trouet D, Carton I, Nilius B. Cellular function and control of volume-regulated anion channels. Cell Biochem Biophys 2001; 35 : 263-74.

4 Sardini A, Amey JS, Weylandt KH, Nobles M, Valverde MA, Higgins CF. Cell volume regulation and swelling-activated chloride channels. Biochim Biophys Acta 2003; 1618: 153-62.

5 Zhou JG, Ren JL, Qiu QY, He H, Guan YY. Regulation of intracellular $\mathrm{Cl}^{-}$ concentration through volume-regulated $\mathrm{CIC}-3$ chloride channels in A10 vascular smooth muscle cells. J Biol Chem 2005; 280: 7301-8.

6 Shi XL, Wang GL, Zhang Z, Liu YJ, Chen JH, Zhou JG, et al. Alteration of volume-regulated chloride movement in rat cerebrovascular smooth muscle cells during hypertension. Hypertension 2007; 49: 1371-7.

7 Liu YJ, Wang XG, Tang YB, Chen JH, Lv XF, Zhou JG, et al. Simvastatin ameliorates rat cerebrovascular remodeling during hypertension via inhibition of volume-regulated chloride channel. Hypertension 2010; 56: 445-52.

8 Hong L, Xie ZZ, Du YH, Tang YB, Tao J, Lv XF, et al. Alteration of volume-regulated chloride channel during macrophage-derived foam cell formation in atherosclerosis. Atherosclerosis 2011; 216: 59-66.

9 Yang $\mathrm{H}$, Huang LY, Zeng DY, Huang EW, Liang SJ, Tang YB, et al. Decrease of intracellular chloride concentration promotes endothelial cell inflammation by activating nuclear factor-kappaB pathway. Hypertension 2012; 60: 1287-93.

10 Duran C, Thompson CH, Xiao Q, Hartzell HC. Chloride channels: often enigmatic, rarely predictable. Ann Rev Physiol 2010; 72: 95-121.

11 Verissimo F, Jordan P. WNK kinases, a novel protein kinase subfamily in multi-cellular organisms. Oncogene 2001; 20: 5562-9.

12 Zambrowicz BP, Abuin A, Ramirez-Solis R, Richter LJ, Piggott J, BeltrandelRio $\mathrm{H}$, et al. Wnk1 kinase deficiency lowers blood pressure in mice: a gene-trap screen to identify potential targets for therapeutic intervention. Proc Natl Acad Sci U S A 2003; 100: 14109-14.

13 Moriguchi T, Urushiyama S, Hisamoto N, lemura S, Uchida S, Natsume
T, et al. WNK1 regulates phosphorylation of cation-chloride-coupled cotransporters via the STE20-related kinases, SPAK and OSR1. J Biol Chem 2005; 280: 42685-93.

14 Delaloy C, Hadchouel J, Imbert-Teboul M, Clemessy M, Houot AM, Jeunemaitre $X$. Cardiovascular expression of the mouse WNK1 gene during development and adulthood revealed by a BAC reporter assay. Am J Pathol 2006; 169: 105-18.

15 McCormick JA, Ellison DH. The WNKs: atypical protein kinases with pleiotropic actions. Physiol Rev 2011; 91: 177-219.

16 Piala AT, Moon TM, Akella R, He H, Cobb MH, Goldsmith EJ. Chloride sensing by WNK1 involves inhibition of autophosphorylation. Sci Signal 2014; 7: ra41.

17 Cheng CJ, Huang CL. Activation of PI3-kinase stimulates endocytosis of ROMK via Akt1/SGK1-dependent phosphorylation of WNK1. J Am Soc Nephrol 2011; 22: 460-71.

18 Wang $M$, Yang $H$, Zheng LY, Zhang Z, Tang YB, Wang GL, et al. Downregulation of TMEM16A calcium-activated chloride channel contributes to cerebrovascular remodeling during hypertension by promoting basilar smooth muscle cell proliferation. Circulation 2012; 125: 697-707.

19 Ma MM, Li SY, Wang M, Guan YY. Simvastatin attenuated cerebrovascular cell proliferation in the development of hypertension through Rho/ Rho-kinase pathway. J Cardiovasc Pharmacol 2012; 59: 576-82.

20 Tang YB, Liu YJ, Zhou JG, Wang GL, Qiu QY, Guan YY. Silence of CIC3 chloride channel inhibits cell proliferation and the cell cycle via G/ $S$ phase arrest in rat basilar arterial smooth muscle cells. Cell Prolifer 2008; 41: 775-85.

21 Kitamura K, Yamazaki J. Chloride channels and their functional roles in smooth muscle tone in the vasculature. Jpn J Pharmacol 2001; 85: 351-7.

22 Chipperfield AR, Harper AA. Chloride in smooth muscle. Prog Biophys Mol Biol 2000; 74: 175-221.

23 Bulley S, Jaggar JH. $\mathrm{Cl}^{-}$channels in smooth muscle cells. Pflugers Arch Eur J Physiol 2014; 466: 861-72.

24 Orlov SN, Koltsova SV, Kapilevich LV, Dulin NO, Gusakova SV. Cationchloride cotransporters: regulation, physiological significance, and role in pathogenesis of arterial hypertension. Biochem Biokhim 2014; 79: 1546-61.

25 Hadchouel J, Ellison DH, Gamba G. Regulation of renal electrolyte transport by WNK and SPAK-OSR1 kinases. Ann Rev Physiol 2016; 78: 367-89.

26 Kahle KT, Ring AM, Lifton RP. Molecular physiology of the WNK kinases. Ann Rev Physiol 2008; 70: 329-55.

27 Bergaya S, Faure S, Baudrie V, Rio M, Escoubet B, Bonnin P, et al. WNK1 regulates vasoconstriction and blood pressure response to alpha 1-adrenergic stimulation in mice. Hypertension 2011; 58 : 439-45.

28 Shiozaki A, Otsuji E, Marunaka Y. Intracellular chloride regulates the $\mathrm{G}_{1} / \mathrm{S}$ cell cycle progression in gastric cancer cells. World J Gastrointest Oncol 2011; 3: 119-22.

29 Wu QQ, Liu XY, Xiong LX, Shang JY, Mai XY, Pang RP, et al. Reduction of intracellular chloride concentration promotes foam cell formation. Circ J 2016; 80: 1024-33.

30 Zagorska A, Pozo-Guisado E, Boudeau J, Vitari AC, Rafiqi FH, Thastrup $J$, et al. Regulation of activity and localization of the WNK1 protein 
kinase by hyperosmotic stress. J Cell Biol 2007; 176: 89-100.

31 Lenertz LY, Lee BH, Min X, Xu BE, Wedin K, Earnest S, et al. Properties of WNK1 and implications for other family members. J Biol Chem 2005; 280: 26653-8.
32 Choe KP, Strange K. Evolutionarily conserved WNK and Ste20 kinases are essential for acute volume recovery and survival after hypertonic shrinkage in Caenorhabditis elegans. Am J Physiol Cell Physiol 2007; 293: C915-27. 